\title{
Gap Junction Alpha-1 Protein
}

National Cancer Institute

\section{Source}

National Cancer Institute. Gap/unction Alpha-1 Protein. NCI Thesaurus. Code C115172.

Gap junction alpha-1 protein (382 aa, $43 \mathrm{kDa}$ ) is encoded by the human GJA1 gene. This protein is involved in the regulation of the assembly of gap junctions. 